\title{
On the Reflection of Naturalism in the Main Character in The Call of the Wild
}

\author{
Xiu Zeng \\ Foreign Language School, Nanchang Normal University, Nanchang, Jiangxi, 330032, China
}

\begin{abstract}
Jack London is one of the most outstanding and celebrated critical realists in American literature in the $2^{\text {th }}$ century, he is well recognized in his artistic creation of literary works with the feature of naturalism. The Call of the Wild is one of his naturalistic works filled with adventure and fighting spirit. The main character of the novel is a dog named Buck. By concentrating on Buck's gradual reversion from a civilized pet to a primordial beast, Jack London demonstrates the power of heredity and environment in determining and shaping one's mind and behaviors. Naturalists believe that mankind is the product of environment, the power of heredity and force of environment are greater than the will of human beings. It is not the strongest of the species that can survive, but the one most responsive to changes. Humans have to adapt themselves to the environment for survival. In The Call of the Wild, the principle of literary naturalism is mainly reflected in the effects of the hereditary and environmental factors on the fate of the main character, Buck.
\end{abstract}

Index Terms — naturalism, adaption, survive

\section{INTRODUCTION}

The Call of the Wild is one of the representative works of the America literary naturalist Jack London. Under the influence of the literary tendency from France, Jack London makes use of naturalistic writing techniques to interpret the reality of American society through the call of wild to Buck and convinces us that man has been predetermined in birth and thus has little free control over his own fate under certain circumstance, it reveals the social truth of the United States at the end of the $19^{\text {th }}$ century.

Buck, the hero of The Call of the Wild, is a dog. His fights and struggles against both the exterior severe natural environment and the interior instinct make up the main frame of the story. In the retrogression in life from the enlightened world to the wild one, Buck has been treated in much cruel and brutal way and has to adjust his beliefs and living ways to adapt himself to the changed and worse living condition for survival, no matter how hard and challenging the experiences are. Finally, he survives the challenge through both his intelligence and strength.

But Buck is more than a dog. He is the embodiment of the strong man in the American industrialization era. Buck struggles in the bottom class and fights against odds for basic rights to survival. He is in an extremely difficult environment full of challenges, and has to constantly overcome them. Buck becomes stronger and stronger by constantly changing himself, he finally adapts himself to the surroundings and survives. Eventually, Buck becomes the leader of the wolves.

Through Buck's life experience, we can clearly understand the hard life of the people at the bottom in the United States in the late $19^{\text {th }}$ century. The metamorphosis of Buck shows us a truth that only those who are endowed with strength and aggression can defeat their opponents and gain the right to survival and wealth. The process of growing up of Buck has reflected the cruel reality of capitalism and an objective rule----survival of the fittest.

\section{A. The Introduction of Jack London}

Jack London was born in San Francisco in 1876. He grew up in extreme poverty, experiencing profoundly the struggle for survival that most other writers and intellectuals knew only from observation or books (Xiaofen Zhang 2010). Due to the hardship in life, for the people he met, and the books he read, he believed in the inevitable triumph of the strongest individuals. His fighting spirit, a deeply felt commitment to the fundamental reality of the law of survival and the will to power, is dramatized in his most popular novels, such as The Call of the Wild(1903) and The Sea Wolf(1904).

Jack London is a resolute and stubborn man. He prefers an adventurous life to a settled one. He regards adventure as a pleasure and sees risk as a joy. Most works of Jack London are masculine, doughty, aggressive and energetic. He likes to record his own personal experiences in his works. His works are not only welcomed by ordinary readers, but also appreciated by scholars. Some people believe that Jack London's works are full of vitality and optimism, others think that it is the combination of civilization, spirit and courage. Jack London's works are praised as highly original, he has a great fame and lofty status in modern American literature and also world literature.

\section{B. The Introduction of The Call of the Wild}

The Call of the Wild is written by Jack London and published in 1903. Today, it is taken as a short adventure story set in Yukon, Canada. It mainly concerns the terrible life experience of the central character, a dog named Buck, and it 
works as a mirror to reflect the scene of the historic events - the 1890s Klondike Gold Rush. At that time, a large number of people are so mad with gold that they rush to Canada with food, equipment and other necessities drawn by carriages and sled dogs. Much demanded as dogs are, Buck is stolen from his master and his respectable home in the south, and sold into service as a sled dog in Alaska. This way, He starts to live in a different place, a much harsher environment, far away from civilization, where he is forced to fight to survive.

In the novel, Buck is an anthropomorphic dog, not an ordinary dog in its common sense, but a dog with life, courage, power and pride. In the depiction of Buck, Jack London attributes human quality (thoughts and insights) to Buck, he has much love for life, pride in his power and pursuit for his own identity that he earns respect and admiration from readers.

In the characterization of Buck, Jack London follows the theory of literary naturalism proposed by European writers such as Émile Zola, and explores the themes--the role heredity and environment play in the development of one's character.

London lived in Yukon for a year and collected much material for the book through close observation. After the story was published in the summer of 1903 the book brought great popularity and success to London.

\section{The Introduction of Social Condition}

In the late $19^{\text {th }}$ century, the United States was in the period when pursuit of money was extremely fierce after the Civil War. The whole country was overrun under the law of jungle. Everyone competed with each other in a cruel competition for survival, status, honor and wealth. In the fall of 1897, people found gold when they groped in the Arctic darkness, and thousands of people rushed into the Northland. This new find intensified the social unrest in the United States. The author placed Buck in an extremely difficult environment when he was creating Buck. Buck had to withstand the test of nature, starvation and cold, even he had to defeat enemies to survive in the primordial forest. Buck's position was exactly the same as that of some Americans at that time. Moreover, before Jack London created The Call of the Wild, he had experienced as a gold digger. In July 1897, Jack London left San Francisco and came to Dawson. He had a deep impression of the natural landscape of Dawson and conceived the basic plot of The Call of the Wild during his life in Dawson.

\section{The Definition AND DEVElopment OF NATURALISM}

According to Webster's New World Dictionary, Naturalism in literature and art refers to the principles and methods held by a group of the $19^{\text {th }}$ century writers, including Emile Zola, Gustave Flaubert, Guy de Maupassant who kept faithful adherence to nature and believed that the writer or artist should apply scientific objectivity and precision in his observation and treatment of life without idealizing, imposing value judgments, or avoiding what may be regarded as repulsive. It was first proposed and formulated by a French novelist Emile Zola, and it was introduced to America by an American novelist Frank Norris (Zhang Xiaofen, 2010). It was spread to America from the late $19^{\text {th }}$ century to the early $20^{\text {th }}$ century. Then a generation of writers arose whose ideas of the workings of the universe and whose perception of social disorders led them to take naturalism, a new and harder realism (Wu Weiren, 1990). American literary naturalists attempted to achieve extreme objectivity and frankness, presenting characters of low social and economic classes who were dominated by their environment and heredity (wu Weiren, 1990). The power of heredity and environment are greater than the will of human beings. Mankind is the product of the environment, there is no way to resist but to adapt to the environment. The Call of the Wild is a typical naturalistic work and objectively reflects the Americans' life through Buck's life. We can't find obvious critical views of the author between the lines, but the novel sends a voice of the author's dissatisfaction with the society. The naturalism in The Call of the Wild mainly reflects the dual effects of genetic and environmental factors on the fate of Buck.

\section{Literary NATURALISM Is REFLECTED IN THE CALL OF THE WILD}

Naturalism is often considered to be part of realism, but American naturalists tend to illustrate law of nature in a scientific and objective way. Naturalists are likely to focus on the dark side of human society, take people in low class for an object of study and explore the root causes for their misery ad hardship. In research for the solution to social problems, naturalists emphasize that gene and environment have a far-reaching impact on the fate of animals and humans(Zhang Xiaofen, 2010). In this essay, focus is mainly put on the role that heredity plays in the life of the main character and the effect of environment that is produced on the character.

\section{A. The Role That Heredity Plays in the Life of the Main Character}

As one of the elements of naturalism, heredity plays an important role in Buck's life. Heredity determines the dog's physical build and strength. Buck's good bloodline gives him a superior intelligence quotient and strong body, superior adaptability and fighting skills. In this novel, hereditary factors are mainly reflected in the following aspects.

\section{Buck's strong build}

The outstanding intelligence quotient and the strong body of Buck are connected with his excellent blood relationship, which shows the power of heredity. The excellent blood relationship makes him an excellent dog. He is tall, big, strong, sturdy, intelligent and quick-witted. He is a dog of one hundred and forty pounds in weight. This comes from his farther, a huge St. Bernard, and his mother, a Scotch shepherd dog. St. Bernard is a kind of rescue dog in the Swiss Snow 
Mountains, while Scotch shepherd is a kind of dog that has to fight with the wolves. Both of them are sturdy, tough, tolerant and huge. The superiorities of Buck's body are inherited from his parents. As an honorable dog, Buck's huge body plays an important part in his surviving and becoming a leader in the harsh north. Buck's body is a main thread that runs through the whole text.

In the fall of 1897, thousands of dragged men were stroke to Klondike from all over the world for a new find-a yellow metal. People wanted to grope in the harsh north where they needed strong dogs with pretty muscles to work and furry coats to protect them from the frost. Unfortunately, Buck is a kind of dog they needed. For this reason, Buck was abducted from the south to the north, from civilization to the primordial. Also, that is why Perrault (Buck's first master) chose Buck and took him to the north.

Buck lived in a savage environment after he was abducted to the north. He had to fight with other dogs inevitably if he wanted to survive. Without his strong body, Buck could not win the fights or could even lose his basic right to survive. When Buck toiled in the north, he had to try to get food for himself through working hard. There were dogs dying of a heavy job, but Buck was different from those weak ones. He is strong enough to fight against the hard environment. Buck was increasingly good at this and did very well in his work and in his later leadership.

\section{Buck's adaptability}

It is not easy for Buck to adapt itself to the harsh north suddenly. What Buck has to get used to is not only the cold in the north, but also the life that fills with savagery, brutality and violence. Life is in peril every moment. What enables Buck to survive is his good genes and great adaptability. Both of his parents are sturdy and live in the snow. Buck is brilliant and strong, and knows that in order to adapt to the cold north, he has to make some changes, both mentally and physically.

For Buck, this is a cruel world. He has to toil under the sled every day in order to get food. The ration for dogs team was gave out by their master. Buck was so ravenous that a pound and a half of ration seemed too limited to satisfy Buck's need. Moreover, other dogs might rob him of his ration sometimes. Therefore, Buck has to give up the fastidiousness and daintiness in which he used to keep. Buck belonged to the snow although he was born in the sunshine; his nature and instinct are still in his blood.

Another adaptability in Buck is reflected in the degradation of his morals. Buck steals a piece of bacon from Perrault, which means he can adjust himself to the change of the environment. Buck knows that the civilization and love he followed before are not applicable here, and he has to make some changes to adapt to the new situation. Buck does that cunningly, so cunningly that he escapes suspicion from Perrault and others. Buck's cunning is inherent from his ancestors.

Toiling in the trace day in and day out, Buck's muscles become hard as iron and he feels nothing for ordinary pain. His soft and tender feet become hard and massive and he could trek in the snow for a long time. Buck is not a king in Judge Miller's place anymore, that is to say, he has to work here and throws his old habits away to adjust the new life.

\section{Buck's fighting skills}

Under the threat of loss of life, Buck has to keep constantly alert. Buck was born with fight in his blood which was inherited from his ancestors. After abducted to the ruthless north, the instinct that slept in Buck's body is awakened inch by inch. His memory goes back to the youth of the breed in a vague way. He remembers the way that the wild dogs range in packs and hunt in the primeval forest, he remembers the way that they fight and hunt by cut and slash. It is unnecessary for Buck to learn to fight, this is a gift given by his ancestors in his blood. The instinct of Buck is alive again, that is to say, his domesticated generations disappear after Buck's animal nature is awakened.

Spitz is the first enemy of Buck when Buck just comes to the north. Buck does not like Spitz at all. He keeps silent first, then he takes off Spitz's coat cunningly, finally he kills Spitz. When they confront each other, Buck feels he has seen this scene before. Buck's fighting skills come from his ancestors, his intelligence comes from his mother. In this fight, Buck wins Spitz by using his skills and intelligence.

Buck goes deep into the forest to seek the call from the forest. He runs, hides, jumps and kills in the primeval forest as his ancestors do. Buck meets the most formidable opponent-- a huge moose of six feet high and seven feet wide leading a team deer with a score of moose. Guided by that instinct which comes from the old hunting days of the primordial world, Buck separates the bull from the deer and kills him.

Buck finally returns to the primeval forest after his last master died. When Buck runs in the forest he meets a pack of wolves. Buck confronts with the wolves alone and in peace, bravery and power, Buck fights like a beast and defeats the wolves. Finally, Buck stays with the wolves and becomes the leader of the wolves.

\section{Buck's loyalty}

Buck's loyalty is also a sign of gene determinism. Buck is saved by Thornton, his last master when he is at death's door. During the time he stays with Thornton, the loyalty in the depth of Buck's heart is awakened. Thornton takes care of Buck as his own child, and Buck feels deeply grateful to Thornton as a son to his father. Buck is well known for pulling a sled which is filled with one thousand pound of flour and which should be pulled by a team of ten dogs. Buck earns sixteen hundred dollars for Thornton so Thornton could pay off his debts. Buck builds quite a good relationship with his master though he is drawn away from civilization. Unfortunately, Thornton is killed by some Yeehats. In revenge for Thornton, Buck attacks them like a Fiend incarnate. Each summer days, Buck crosses the timber land and comes down into an open space among the trees where Thornton was killed. Buck muses for a while, howling long and 
mournfully, and then he departs. He keeps Thornton in his memory as a friend and shows deep gratitude to his master.

\section{B. The Effect of Environment on the Character}

As one of the most important factors of naturalism, the effect of environment on Buck can be seen in the whole works. The change of environment turns Buck into a leader in the wild from a pet of civilized society. Buck has life experiences in three different environments: living in the south before abducted, living in the north after abducted, returning to the primeval forest after Thornton died. Buck's destiny changes with the change of environment, which proves the theory of Charles Darwin-- It is not the strongest of the species that survive, but the one most responsive to change.

The process of adapting to the social environment also reflects the environment determinism. Buck is inferior in front of the humans armed with clubs, he chooses to compromise and accepts the fate, but at the appropriate time he will fight back. This is the influence of social environment on the psychology of Buck.

\section{A King of the House in the civilized society}

There is a big house named Judge Miller's place, seated in the sun-kissed Santa Clara Valley. Buck was born and grew up like a noble right here. Obviously, at the beginning of the novel, Buck belongs to the civilized society where he is a polite dog with "human nature". Judge Miller's place is a symbol of a civilized society where Buck is taken as a king and spends all day on swimming, hunting, playing and taking adventures with the Millers, where Buck utterly ignores others for he is the king over all of the animals. In the winter, he lays down before the roaring library fire. In the summer, he plunges into the swimming tank to play. Such a good living enables him to carry himself dignity and a royal fashion.

In the general civilized south, Buck grows up into a gentleman, elegant, kind and friendly, until the gardener's helper gets a chance to abduct him, thus all is different.

\section{A primordial beast in the wildness}

After abducted to the cold north, Buck has suffered great changes to adapt to the living environment where he masters many skills for survival. At the beginning, he even does not know how to sleep in the world of ice and snow, but he learns to lie under the snow and curls into a warm ball quickly. The manner of eating is no longer gentlemanlike as before and he even robs and steals from others. The cruel living environment changes Buck so much.

In the wilderness, the only principle is "the law of club and tooth" (Jack London,1903). When Buck realizes that he is in such a "to kill or to be killed" wilderness, savagery and brutality no longer leaves any room for the code of polite behavior and morality, therefore, he must adjust himself to adapt to the cruel life. He is used to living in the south where it is full of sunshine, warmth, friendship and love. Opposite to the south, there is no peace but endless work, savages, dangers and fights. Buck is no longer the king at all, but a labour. He has to toil for food and struggles for survival. He changes his habits and the rule of behaviors. He replaces dignity with indecency, innocence with cunning, civilization with wildness and elegance with rudeness.

Under the force of the environment, Buck retrogresses soon and he gets rid of the southern civilization on him. The dominant primordial beast in him becomes increasingly stronger and the hidden wildness is awakened gradually, the instincts of their ancestors returns unwittingly.

\section{A Head in the primeval forest}

During the period of toil in the north, Buck's wild nature is awaking gradually and he is always attracted by a call in a familiar way from the forest (Jack London,1903). He can't help following the call and goes deeply into the primeval forest. In the end, Buck becomes a completely cunning primitive animal in the forest. The challenge there is more dangerous than that in the north and the rivals are stronger and more formidable than those sled dogs.

Buck has a lesson that only the fiercest and wildest dog can control his own destiny. After Buck returns to the primeval forest, he meets a score of moose and a pack of wolves. Buck fights like a jungle king, as if he was born to fight and then takes an upper hand in the battles against his rivals. Finally, Buck lives with the wolves and becomes the leader of the wolves.

To take leadership finally over the other dogs partly comes from his natural endowment-strong physical build, partly from his firm determination, his courage, his pride--not to be defeated and conquered. In this aspect, Jack London attributes Buck with human unyielding spirit, especially, the west spirit in America.

\section{CONCLUSION}

The image of Buck in The Call of the Wild is a true reflection of literary naturalism. It is an illustration of the dominating effect of hereditary and environmental factors on the fate of animals and humans. Buck's quick response to the call of the wild and new environment is much determined by the genes passed down from his ancestors. Buck's final regression from a civilized pet to a head over the wild dogs is a proof to the role of environment in molding one's character.

The image of Buck in The Call of the Wild is also an embodiment of the recognized law of jungle advanced by Darwin: "the survival of the fittest". - humans or animals have to compete against any odds or any rivals in harsh living condition in order to survive. Such a law echoes the "to kill or to be killed" rule in the far and savage animal world though it rebels against the generally accepted high morality in modern human world. To Buck, to survive is to fight in 
a bloody battle where there is no rule, no mercy, no negotiation but fight and survival.

\section{REFERENCES}

[1] Charles Darwin. (2011). The Origin of Species. New York: Harper Collins Publisher.

[2] David B. Guralnik. (1980). Webster's New World Dictionary of the American Language. The Unite States: William Collins Publisher, INC.

[3] Jack London. (1903). The Call of the Wild. The Unite States: Macmillan.

[4] Wu Weiren. (1990). History and Anthology of American Literature. Beijing: Foreign Language Teaching and Research Press.

[5] Zhang Xiaofen. (2010). Naturalism Present in the Call of the Wild. Journal of Language Teaching and Research, 1, $278-281$.

Xiu Zeng was born in Nanchang, China in 1964. She received her M.A in British language and literature from Jiangxi university (Nanchang university thus named today), China in 1986.

She is currently an associate professor in the Foreign Language School, Nanchang Normal University, Nanchang, Jiangxi, China. Her research interest includes American literature.

Ms. Zeng is a member of the Jiangxi Association of Foreign Language Teachers. 